\title{
Tuberculosis among immigrants in the United Kingdom: the role of occupational health services
}

\author{
M. KHOG ALI \\ From the London School of Hygiene and Tropical Medicine
}

Immigrant workers in the United Kingdom account for $\mathbf{7 \cdot 8 \%}$ of the working population. Their health problems fall into three groups-imported diseases, occupational accidents, and acquired diseases. In the latter group, tuberculosis is still a major problem. A retrospective study tracing notifiable cases of tuberculosis to points of entry at Heathrow Airport indicates that the majority of immigrants acquire the disease after entry. The occupational health services have a great role to play in detecting the new cases very early and in providing appropriate screening and follow-up. Proper co-ordination between occupational and community health services will give the best results and lead to a rapid decline of the disease.

We first hear of coloured immigrants in England in 1555 (Skone, 1962) but their number was insignificant. In 1851 there were 700000 Irish immigrants in Britain. They were followed by Italians and by about 120000 Jews who came to Britain between 1875 and 1914 from eastern Europe (Power, 1976). During and after the First World War the number of aliens settling in the United Kingdom decreased sharply.

After the Second World War, migrant workers were in demand because of the labour shortage. During the war 120000 Poles came in and they were employed in areas of labour shortage such as the mines. From 1949 a growing stream of migrants began to arrive from the West Indies, some having been recruited in their own countries to work in London Transport and British industries.

The 1971 census shows that the total number of immigrants, that is, those not born in the United Kingdom, was 3164375 persons, or $6.5 \%$ of the population (Office of Population Censuses and Surveys, 1974). The total coloured population was 1331000 persons, representing $2.5 \%$ of the resident population, and distributed as follows: $41 \%$ West Indians, 29\% Indians, 13\% Pakistanis, 12\% Africans and $5 \%$ others. The census also showed a tendency among coloured immigrants to settle and cluster in certain geographical areas, mainly near industrial centres.

Immigrants come to this country mainly to take jobs. In 1974, 1800000 immigrant workers were in employment ( $7 \cdot 8 \%$ of the working population). Mos were Irish or from the Commonwealth countries. survey conducted by Lawrence (1974) showed thas $c$ the majority of immigrants were categorised as belonging to Social Classes IV and V. They are alse. predominantly unskilled (Department of Employment, 1972).

HEALTH PROBLEMS OF IMMIGRANTS

These can be divided into three groups. The first consists of imported diseases, most of which are cases of parasitosis. Such cases are rendered non-communicable in the environmental conditions prevailing in this country, so they do not represent a major hazard to the public or to other immigrants. Nevertheless, they affect the general health and resistance of the affected immigrant worker.

The second group consists of occupational accidents, which are more common and more severe among foreign workers than among indigenous workers (World Health Organisation, 1975).

The third group of health problems include those diseases acquired or activated in the new countries. Psychotic disorders, venereal diseases, and tuberculosis are the most important. The psychotic disorders present either as a classic or as a reactive psychosis (Hashmi, 1970; Bagley, 1971).

T U B E R C U L OS IS

Tuberculosis is still a major problem in the United Kingdom. There are 8000 notifications every year 
and the present annual cost of tuberculosis for England and Wales is well in excess of $£ 40$ million (Reid, 1976). The two surveys of 1965 and 1971 carried out by the British Thoracic and Tuberculosis Association (BTTA, 1973) have shown that a higher rate of tuberculosis in immigrants is the most obvious factor contributing to the problem of tuberculosis in Britain (Table 1). In the 1971 survey it was found

Table 1 Change in notifications of tuberculosis 1965 to 1971

\begin{tabular}{lcclll}
\hline & \multicolumn{2}{l}{ No. per 100000} & & \multicolumn{2}{l}{ Ratio rate for British Isles } \\
\cline { 2 - 3 } \cline { 6 - 7 } Place of birth & 1965 & 1971 & & 1965 & 1971 \\
\hline BRITISH ISLES & 2.3 & 1.3 & & x1 & x1 \\
Africa & 9.3 & 13.0 & & x4 & x10 \\
India & 27.0 & 34.5 & & x12 & x27 \\
Pakistan & 57.0 & 70.0 & & x25 & x54 \\
West Indies & 5.8 & 3.3 & & x3 & x3 \\
\hline
\end{tabular}

Source: British Thoraric and Tuberculosis Association (1973).

that $32 \%$ of those notified were born outside Britain. For those born in Africa, India, and Pakistan, tuberculosis was found to be respectively 10,27 , and 54 times higher than for those born in England and Wales. The BTTA concluded their studies: 'It is not known whether their disease is "active" on arrival in Britain or whether, after arrival, new disease is acquired or quiescent disease relapses' (BTTA, 1973).

On the basis of these studies, and in an attempt to throw some light on this problem, the following retrospective study was planned.

\section{X-RAY SYSTEM AT}

\section{HEATHROW AIRPORT}

Approximately $90 \%$ of immigrants enter the United Kingdom through Heathrow Airport. All $x$-rays are taken in the Health Control Unit (HCU) in Terminal 3. Between 1965 and 1975, 402583 New Commonwealth immigrants were seen at the HCU. Of these, 73619 were $x$ rayed.

The $x$-ray unit, an Odelca $100 \mathrm{~mm}$ mass $x$-ray machine, was introduced in February 1965. The $x$-ray is first read by the duty medical officer and if it appears to be normal the immigrant goes to customs clearance. His name and address are written on the $x$-ray envelope. Every week the accumulated films are re-read by a visiting consultant radiologist. If an abnormality has been missed, he can get in touch with the local environmental health physician, giving details of his findings and the immigrant's name and address.

At Heathrow all relevant details about the immigrant-name, year of birth, and nationality-are taken from the passport and recorded in the day book. When $x$ rayed he is also recorded in another $x$-ray day book and cross-referenced in the day book. If $x$-rays require further inspection these are entered into a referred $x$-ray cases book.

\section{Material and methods}

Notifiable cases were collected from (1) the data of the BTTA survey on tuberculosis among immigrant populations (February to May 1971) and (2) cases of tuberculosis among immigrants notified in 1975 by Birmingham Chest Clinic and by Willesden Chest Clinic in the London borough of Brent. Both areas have a large immigrant population. The BTTA data were used because these were the only reliable national data available. These cases were then traced back to the point of entry at Heathrow Airport. Records at the Health Control Unit were checked to see if these patients were $x$ rayed on entry or not, and, if they were, what was the result and the diagnosis.

Certain categories were excluded from the cases collected. These were (a) patients who entered the country before the introduction of the $x$-ray unit in Heathrow Airport in February 1965, and (b) all patients aged under 15 on the date of entry. For each person the following information was then recorded: name, sex, nationality and country of origin, date of birth, date of entry into the United Kingdom, date of notification, and type and extent of the disease.

\section{Results}

Of a total of 1189 notified cases, only 843 were included in the study (Table 2). These were composed of 353 Indians, 320 Pakistanis, 145 Africans, and 25 from other countries; $45 \%$ were in the age group $15-24$ years and $71 \%$ were under 35 .

Of the 843 persons, only $62(7 \cdot 3 \%)$ were traced in the HCU records at Heathrow. Fifty-five were $x$ rayed on entry, of whom 36 had normal $x$-rays at that time. Nineteen persons were found to have abnormal $x$-rays (Table 3 ).

Table 2 Analysis of cases included in the study

\begin{tabular}{llll}
\hline & & \multicolumn{2}{l}{ Cases included in the study } \\
\cline { 3 - 4 } Source & No. notified & No. & $\%$ \\
\hline BTTA (1971) & 654 & 473 & 72 \\
Willesden Chest Clinic & 269 & 233 & 81 \\
$\begin{array}{l}\text { (1975) } \\
\text { Birmingham Chest }\end{array}$ & 266 & 137 & 52 \\
$\begin{array}{l}\text { Clinic (1975) } \\
\text { Total }\end{array}$ & 1189 & 843 & 71 \\
\hline
\end{tabular}


Table 3 Number of persons examined and number $x$ rayed at the Health Control Unit 1965 to 1975, and cases of tuberculosis located in the HCU records

\begin{tabular}{|c|c|c|c|c|c|}
\hline \multirow[b]{2}{*}{ Period } & \multirow[b]{2}{*}{$x$ rayed } & \multirow[b]{2}{*}{ Total examined by $\mathrm{HCU}$} & \multicolumn{3}{|l|}{ Cases located in records } \\
\hline & & & Found abnormal at $\mathrm{HCU}$ & Found normal at $\mathrm{HCU}$ & Total \\
\hline $1965-67$ & $\begin{array}{l}\text { No } \\
\text { Yes }\end{array}$ & $\begin{array}{l}25536 \\
15290\end{array}$ & $\begin{array}{c}\text { NK } \\
1\end{array}$ & $\begin{array}{c}\text { NK } \\
6\end{array}$ & $\begin{array}{c}\text { NK } \\
7\end{array}$ \\
\hline $1968-74$ & $\begin{array}{l}\text { No } \\
\text { Yes }\end{array}$ & $\begin{array}{r}251360 \\
50094\end{array}$ & $\underset{7}{\text { NK }}$ & $\begin{array}{l}\text { NK } \\
30\end{array}$ & $\begin{array}{l}\text { NK } \\
37\end{array}$ \\
\hline 1975 & $\begin{array}{l}\text { No } \\
\text { Yes }\end{array}$ & $\begin{array}{r}51068 \\
8235\end{array}$ & $\begin{array}{l}\text { NK } \\
11\end{array}$ & $\begin{array}{c}\text { NK } \\
0\end{array}$ & $\begin{array}{l}\text { NK } \\
11\end{array}$ \\
\hline $1965-75$ & $\begin{array}{l}\text { No } \\
\text { Yes }\end{array}$ & $\begin{array}{r}328964 \\
73619\end{array}$ & $\begin{array}{l}\text { NK } \\
19\end{array}$ & $\begin{array}{l}\text { NK } \\
36\end{array}$ & $\begin{array}{l}\text { NK } \\
55\end{array}$ \\
\hline
\end{tabular}

NK $=$ Not known

\section{Discussion}

The number of cases traced back to the $\mathrm{HCU}$ records is very small and this makes it difficult to draw conclusions. Nevertheless, the 36 persons who had normal $x$-rays on entry represent $65 \%$ of the 55 persons $x$ rayed. The seven persons who were identified in the records but not $x$ rayed would have yielded one case if their $x$-rays had actually been taken. This trend indicates that the majority of immigrants acquire the disease after entry. It also gives support to the opinion of the Joint Tuberculosis Committee (1978) that even if $100 \% x$-ray coverage is made available for all immigrants it would not affect the much greater incidence of disease that develops after arrival'.

\section{ROLE OF OCCUPATIONAL HEALTH SERVICES}

Most of the immigrants come looking for work and they are usually aged $20-34$ years. They are very mobile during their first few years here, and the address of their destination given at Heathrow Airport is a temporary one. Also, they might avoid going to the general practitioner or the hospital if they felt ill, in case it interfered with their work and earnings.

But immigrants cannot avoid undergoing a pre-employment medical examination, or periodical examinations at their places of employment. I suggest that $x$-rays should be taken at the first pre-employment examination and a tuberculin test carried out for each new immigrant worker; if this is found negative (Heaf grade 0 and 1), he should be vaccinated. Every new immigrant worker should be $x$ rayed every six months during the first two years. If he changes employment he should carry a card from his previous place of work. This procedure would guarantee detection of the new cases very early. The occupational health services have a great role to play in this; besides the $x$-ray and vaccination, health education in the place of work is also very important.

The programme of action suggested by the Joint Tuberculosis Committee concentrates mainly on places of settlement. This would be effective because the majority of immigrants cluser round industrial centres and can easily be reached. But the programme would be more effective if the breade winners were approached at their places of employment. Proper coordination between the community health services and the occupationak health services would give the best results and couldo lead to a rapid decline in the disease.

This study was carried out with the help of Dr. P. R: Cooper, Principal Medical Officer, Heathrow Airport, and his staff. I also thank Dr. V. H. Springett, Dr. H. McNichol, Dr. I. Sutherland, Dr. A. Somner, and Dr. M. El Batawi for their help and advice.

Reprints from Dr. M. Khogali, Senior Research Fellow, London School of Hygiene and Tropical Medicine, Keppel Street, London WC1E 7HT.

\section{References}

Bagley, C. (1971). The social aetiology of schizophrenia in immigrant groups. International Journal of Social Psychiatry, 17, 292-304.

British Thoracic and Tuberculosis Association (1973). A tuberculosis survey in England and Wales 1971: the influence of immigration and country of birth upon notifications. Tubercule, 54, 249-260.

Department of Employment (1972). Report on a Survey into Immigrant Labour Relations at Seven English Firms. HMSO: London.

Hashmi, F. (1970). Immigrants and emotional stress. Proceedings of the Royal Society of Medicine, 63, 631-632.

Joint Tuberculosis Committee (1978). Tuberculosis among immigrants in Britain. British Medical Journal, 1, 1038-1040.

Lawrence, D. (1974). Black Migrants; White Natives. Cambridge University Press. 
Office of Population Censuses and Surveys (1974). Country of birth and colour 1971-1974. Population Trends, 2, HMSO: London.

Power, Jonathan (1976). Western Europe's Migrant Workers. Report No. 38. Minority Rights Group: London.

Reid, J. R. (1976). The cost of tuberculosis in England and Wales. Paper read at symposium on tuberculosis at the Department of Health and Social Security, London, April 1976.
Skone, J. F. (1962). The health and social welfare of immigrants in Britain. Public Health, 76, 132-148.

World Health Organisation (1975). Health Aspects of Labour Migration. Report of a working group. Algiers 6th-9th March 1973. WHO: Copenhagen. 